\title{
Тетяна Дракохруст,
}

кандидат наук з державного управління, дочент, завідувач кафедри міжнародного права та міграційної політики Тернопільського національного економічного університету ORCID 0000-0002-4761-7943

\section{АДМІНІСТРАТИВНО-ПРАВОВІ ФОРМИ ТА МЕТОДИ ЗАПОБІГАННЯ ПІДРОЗДІЛАМИ ГРОМАДСЬКОЇ БЕЗПЕКИ НАЦІОНАЛЬНОЇ ПОЛІЦІЇ НЕЛЕГАЛЬНІЙ МІГРАЦІї}

Розглянуто особливості адміністративно-правових форм та методів запобігання підрозділами громадської безпеки національної полічії нелегальній міграції. Зазначено, увесь перелік нормативно-правових актів, які регламентують заходи органів внутрімніх справ Украӥни щзодо запобігання нелегальній міграції. Акиентує увагу на тому, щзо адміністративна діяльність полічії щзодо протидії нелегальній міграції має конкретні характерні риси. Вказано, щзо значну роботу щзодо запобігання нелегальній міграції проводять підрозділи поліції громадської безпеки, передусім чергові частини, до яких приводять затриманих нелегалів. Як окремий вид (форму) контролю розглядають нагляд, застосування якого в разі виявлення порушень може супроводжуватись заходами впливу державно-владного характеру. Основною формою запобігання нелегальній міграцї підрозділами полічії громадської безпеки є проведення спеціальних операцій: «Мігрант», «Іноземецьь», «Кордон», «Рубіж», «Підприємецьь», «Студент» тощзо. Адміністративною службою МВС України щзомісячно проводяться моніторинги по затриманих нелегальних мігрантах, щьо знаходяться в приймальниках-розподільниках та ізоляторах тимчасового утримання. Зазначено, щзо спільними діями територіальні органи і підрозділи ДМС та НПУ виявили та прийняли рішення про примусове повернення мігрантів, іноземиів було розміщено у пунктах тимчасового перебування іноземиів та осіб без громадянства, заборонено в '̈̈з до України, також прийнято чимало рімень про примусове видворення мігрантів. Зроблено висновок, щзо найбільш активними методами попереджувальної роботи є метод попередження з використанням ЗМI, дипломатичних $і$ консульських установ інших держав та взаємообмін інформаціями з правоохоронними органами України та інших держав. С нагальна потреба ефективної взаємодії між органами державної влади для запобігання нелегальній міграції та створення іміджу держави, яка здатна контролювати власну територію, захищати державні кордони та забезпечувати високий рівень національної безпеки в міграційній сфері.

Ключові слова: нелегальна міграчія, національна полічія, органи внутрішніх справ, адміністративноправові форми, адміністративно-правові методи.

\begin{abstract}
Drakokhrust T.
Administrative and legal forms and methods of preventing the national police units of public security from illegal migration

The article deals with the peculiarities of administrative legal forms and methods of preventing the national police units of public security from illegal migration. Auto specifies the entire list of legal acts that regulate the measures of the law-enforcement bodies of Ukraine to prevent illegal migration. The author emphasizes that the administrative activities of the police in combating illegal migration have specific characteristics. The article also notes that significant efforts to prevent illegal migration are being carried out by public security units, most notably the detachment of detainees. Supervision is considered as a separate type (form) of control, the application of which in the detection of violations may be accompanied by measures of influence of the state-power character. The main form of prevention of illegal migration by the units of the public security police is the conduct of special operations: "Migrant», "Foreigner», "Border», "Border», "Entrepreneur», «Student», etc. The administrative service of the Ministry of Internal Affairs of Ukraine monitors on a monthly basis the detained illegal migrants who are in detention centers and temporary detention centers. The author notes that by joint actions the territorial bodies and units of the LCA and the NGU have identified and made a decision on the forced return of migrants, foreigners have been placed in temporary detention centers for foreigners and stateless persons, banned entry into Ukraine. The author has come to the conclusion that the most active methods of preventive work are the method of warning using the media, diplomatic and consular institutions of other
\end{abstract}

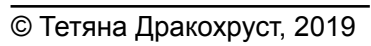


countries and the exchange of information with law enforcement agencies of Ukraine and other countries. There is an urgent need for effective interaction between public authorities to prevent illegal migration and to create an image of the state capable of controlling its own territory, protecting state borders and ensuring a high level of national security in the migration sphere.

Keywords: illegal migration, national police, law enforcement agencies, administrative forms, administrative and legal methods.

Постановка проблеми. Високий рівень нелегальної міграції викликає стурбованість, оскільки спричиняє негативні наслідки і загрози для суспільства й держави. Підвищується рівень криміналізації суспільства, зокрема збільшується кількість мігрантів, які переховуються від закону, злочинців, терористів, швидко розвивається корупція та організована злочинність, пов'язана з незаконним ввезенням мігрантів, учиненням злочинів як мігрантами, так і щодо них, зростанням рівня «супровідних» злочинів (торгівлі людьми та зброєю, наркобізнесу, тероризму тощо).

Крім того, відзначається зростання тіньової економіки і розширення нелегального ринку праці, виникає міжнаціональна напруженість, з’являються нові політичні й економічні загрози для держави. Отже, нелегальна міграція своїм існуванням створює потенційну та реальну загрозу належному функціонуванню нашої держави, оскільки потік нелегальних іммігрантів є безпосереднім викликом безпеці. Йдеться, з одного боку, про безпеку держави як приймаючої сторони, а з іншого - про безпеку людей.

Аналіз наукових досліджень та публікацій. Питаннями нелегальної міграції та методам іiї запобігання, подолання міграційної кризи займалися: С. Братков, Н. Тиндик, Л. Рибаковський, А. Хомра, Ю. Римаренко, С. Мосьондз, С. Денисюк, Б. Хорев та ін.

Мета статті - дослідити специфіку адміністративно-правових форм та методів запобігання підрозділами громадської безпеки національної поліції нелегальній міграції.

Виклад основного матеріалу дослідження. Основними нормативно-правовими документами, які регламентують заходи органів внутрішніх справ України щодо запобігання нелегальній міграції, є Конституція України [1], Закони України «Про національну поліцію» [2], «Про імміграцію» [3], «Про правовий статус іноземців та осіб без громадянства» [4], «Про державну прикордонну службу України» [5], Постанови Кабінету Міністрів України №1074-95 «Правила в’їзду іноземців в Україну, їх виїзду з України і транзитного проїзду через ії територію» [6], № 227-99 «Правила оформлення візових документів для в’”ізду в Україну» [7], Указ Президента України «Про додаткові заходи щодо реалізації права людини на свободу пересування і вільний вибір місця проживання», Указ Президента України «Про заходи щодо посилення боротьби з незаконною міграцією», а також накази, інструкції та листи МВС України.

Виходячи з аналізу ст. 23 Закону України «Про Національну поліцію», до повноважень поліції, які, зокрема, реалізовуються щодо протидії нелегальній міграції, належать такі: 1) здійснення превентивної та профілактичної діяльності, спрямованої на запобігання вчиненню правопорушень; 2) виявлення причин та умов, що сприяють вчиненню кримінальних та адміністративних правопорушень, вживання у межах своєї компетенції заходів для їх усунення; 3) вживання заходів щодо виявлення кримінальних, адміністративних правопорушень; припинення виявлених кримінальних та адміністративних правопорушень; 4) здійснення своєчасного реагування на заяви та повідомлення про кримінальні, адміністративні правопорушення або події; 5) розшук осіб, які переховуються від органів досудового розслідування, слідчого судді, суду, ухиляються від виконання кримінального покарання, пропали безвісти, та інших осіб у випадках, визначених законом; 6) у випадках, визначених законом, здійснення провадження у справах про адміністративні правопорушення, забезпечення виконання рішень про застосування адміністративних стягнень; 7) доставляння у випадках і порядку, визначених законом, затриманих осіб, підозрюваних у вчиненні кримінального правопорушення, та осіб, які вчинили адміністративне правопорушення; 8) вживання заходів для забезпечення публічної безпеки і порядку на вулицях, площах, у парках, скверах, на стадіонах, вокзалах, в аеропортах, морських та річкових портах, інших публічних місцях.

У процесі реалізації своїх повноважень поліція активно використовує різноманітні за характером, формами і методами засоби та способи впливу на суспільні відносини з метою їх упорядкування. Серед цієї сукупності засобів можемо виокремити, як їх визначають в юридичній літературі, адміністративноправові засоби.

Практична реалізація адміністративно-правових засобів здійснюється в межах діяльності, яка в юридичній літературі отримала назву адміністративної. Адміністративна діяльність поліції щодо протидії нелегальній міграції має такі характерні риси: державно-розпорядчий та підзаконний характер; державно- 
владний характер; підпорядкованість і підконтрольність у процесі ії здійснення; законність; профілактичну спрямованість. Крім того, у процесі здійснення адміністративної діяльності щодо протидії нелегальній міграції поліція реалізовує контрольно-наглядові повноваження.

Сутність державного контролю полягає у спостереженні та перевірці розвитку суспільної системи й усіх її елементів відповідно до визначених напрямів, а також у попередженні та виправленні можливих помилок і неправомірних дій, що перешкоджають такому розвитку. Як окремий вид (форму) контролю розглядають нагляд, застосування якого в разі виявлення порушень може супроводжуватись заходами впливу державно-владного характеру [8, с. 231-232].

Органи внутрішніх справ України відповідно до визначених законом завдань, мають такі обов'язки:

- організація запобігання злочинам та адміністративним правопорушенням, протидію яких законодавством віднесено до компетенції органів внутрішніх справ, їх виявлення, припинення, проведення дізнання, здійснення провадження у справах про адміністративні правопорушення згідно із законами;

- запобігання та недопущення в’їзду в Україну або виїзду з України осіб, яким згідно із законодавством не дозволяється в’їзд в Україну або яких тимчасово обмежено у праві виїзду з України, у тому числі згідно з дорученням конкретних правоохоронних органів; розшук в прикордонних зонах та пунктах пропуску через державний кордон осіб, які переховуються від органів дізнання, слідства та суду, ухиляються від відбуття кримінальних покарань; виконання в установленому порядку інших доручень правоохоронних органів;

- організація відповідно до законодавства та прийняття заяв про надання статусу біженців від осіб, які мають намір його набути та змушені були незаконно перетнути державний кордон України;

- прийняття у взаємодії зі Службою безпеки України рішень про видворення за межі України іноземців та осіб без громадянства, які затримані в межах прикордонних зон при спробі або після незаконного перетинання державного кордону України, видворення цих осіб;

- здійснення самостійно або у взаємодії з Державною прикордонною службою,і з Службою безпеки України в межах контрольованих прикордонних районів контролю за дотриманням іноземцями та особами без громадянства, а також біженцями та особами, яким не надано притулок в Україні, установлених правил перебування на їі території;

- охорона, конвоювання та тримання затриманих осіб - власників авто - і плавзасобів до моменту їх передачі органам внутрішніх справ (прикордонної служби) суміжної держави, іншим правоохоронним органам України або суду;

- участь у межах своєї компетенції у взаємодії зі Службою безпеки України у боротьбі з тероризмом і виконанні інших покладених на них завдань.

Основною формою запобігання нелегальній міграції підрозділами поліції громадської безпеки є проведення спеціальних операцій: «Мігрант», «Іноземець», «Кордон», «Рубіж», «Підприємець», «Студент», «Турист», «Магістраль» та ін. До проведення цих операцій залучаються не тільки служби МВС України - ДДГІРФО, ГУБОЗ, ДКМСН, ДДСБЕЗ, а й інші міністерства та відомства: Мінтранс України, Державна туристична адміністрація, Міністерство освіти та науки, Державна прикордонна служба. Роботу з питань нелегальної міграції координує Державна міграційна служба України.

Значну роботу щодо запобігання нелегальній міграції проводять підрозділи поліції громадської безпеки, передусім чергові частини, до яких приводять затриманих нелегалів.

Чергові частини приймають доставлених іноземних громадян, здійснюють перевірки та причетність їх до скоєння злочинів та інших правопорушень, на предмет знаходження в розшуку, відповідності анкетних даних тим, які вони повідомили, вживають інші заходи, передбачені чинними нормативно-правовими актами. Так, згідно з наказом МВС України «Про затвердження Інструкції з організації діяльності чергової служби органів (підрозділів) Національної поліції України» від 23.05.2017 року та спільного наказу Держкомкордону України і МВС України «Про затвердження Інструкції про порядок передачі підрозділами Прикордонних військ України іноземних громадян та осіб без громадянства, що є порушниками законодавства України про державний кордон і правовий статус іноземців, приймання зазначених осіб органами МВС України, їх утримання та видворення за межі держави» від 12.11.2004 року, приймання зазначених осіб органами МВС України, їх утримання та видворення за межі України, вживають інших заходів, передбачених чинним законодавством. Крім того, чергові частини при затриманні групи нелегальних мігрантів терміново залучають членів позаштатної групи протидії нелегальній міграції, перекладачів, а вилучену готівку в затриманих нелегальних мігрантів протягом доби передають на тимчасове зберігання до фінансової частини, з можливим подальшим її використанням для видворення. Це є практичним кроком до здійснення механізму видворення нелегальних мігрантів за межі України не повністю за кошти країни. 
Водночас великий внесок у профілактику запобігання нелегальній міграції вносять підрозділи нацполіції громадської безпеки - служби дільничних інспекторів поліції, патрульно-постова служба, підрозділи швидкого реагування «Беркут». Вони організовують роботу щодо виявлення: нелегальних мігрантів, встановлення іноземців, що знаходяться в Україні з порушенням правил перебування і транзитного проїзду через її територію, та осіб, які надають притулок і незаконні послуги.

Адміністративною службою МВС України щомісячно проводяться моніторинги щодо затриманих нелегальних мігрантів, що знаходяться в приймальниках-розподільниках та ізоляторах тимчасового утримання. Патрульно-постова служба під час охорони громадського порядку здійснює перевірку документів на право перебування іноземців на території України. В разі виявлення нелегальних мігрантів у місцях їх концентрації доставляють їх до чергових частин з метою документування факту їх незаконного перебування в Україні.

31 по 31 серпня 2018 р. ДМС, Нацполіція та Держприкордонслужба спільно проводили цільові превентивні заходи під умовною назвою «Мігрант», спрямовані на запобігання та протидію нелегальній міграції та іншим порушенням законодавства України в міграційній сфері. В рамках операції «Мігрант» виявлено понад 2400 порушників міграційного законодавства».

Зазначається, що спільними діями територіальні органи і підрозділи ДМС та НПУ виявили та прийняли рішення про примусове повернення 2191 мігрантів, 196 іноземців було розміщено у пунктах тимчасового перебування іноземців та осіб без громадянства, 672 - заборонено в’їзд до України, також прийнято 227 рішень про примусове видворення мігрантів.

За порушення міграційного законодавства майже 5,5 тис. іноземців та громадян України було притягнуто до адміністративної відповідальності [9].

Висновки. Особливу увагу приділяють роботі дільничним інспекторам у прикордонних районах України. Насамперед це профілактична та роз'яснювальна робота серед населення про те, що за сприяння нелегальній міграції особу може бути притягнуто до адміністративної або кримінальної відповідальності. Вони широко залучають до цієї роботи членів громадських формувань, населення, представників органів місцевого самоврядування та позаштатних інспекторів Державної прикордонної служби.

Так, основними формами попереджувальної роботи щодо запобігання нелегальній міграції є проведення спеціальних операцій підрозділами нацполіції громадської безпеки «Мігрант», «Студент», «Турист», «Кордон» та іншими.

Найбільш активними методами попереджувальної роботи є попередження з використанням 3МI, дипломатичних і консульських установ інших держав та взаємообмін інформаціями 3 правоохоронними органами України та інших держав.

Питання протидії нелегальній міграції потребують кардинальних претворень. Є нагальна потреба ефективної взаємодії між органами державної влади для запобігання нелегальній міграції та створення іміджу держави, яка здатна контролювати власну територію, захищати державні кордони та забезпечувати високий рівень національної безпеки в міграційній сфері.

\section{Список використаних джерел}

1. Конституція України: прийнята Верховною Радою України 28 червня 1996 року. Відомості Верховної Ради України. 1996. № 30. Ст. 33.

2. Про національну поліцію: Закон України від 02.07.2015. Відомості Верховної Ради України. 2015. № 40-41. Ст. 379.

3. Про імміграцію: Закон України від 07 червня 2001 року. Відомості Верховної Ради України. 2001. № 41. Ст. 197.

4. Про правовий статус іноземців та осіб без громадянства: Закон України від 4 лютого 1994 року. Bidoмості Верховної Ради Украӥни. 1994. № 23.

5. Про Державну прикордонну службу України: Закон України від 3 квітня 2003 року. Вiдомості Верховної Ради України. 2003. № 27.

6. Правила в’їзду іноземців та осіб без громадянства в Україну, їх виїзду з України і транзитного проїзду через іiі територію: Постанова Кабінету Міністрів України від 29 грудня 1995 року № 1074 із змінами та доповненнями станом на 04 вересня 2009 р. Збірник Постанов України. 1995. № 4.

7. Про запровадження нового порядку оформлення візових документів для в'їзду в Україну: Постанова Кабінету Міністрів України від 20 лютого 1999 року № 227. Украйнський часопис права $i$ політики. 1999. № 3. 
8. Адміністративна діяльність органів поліції України : підручник / за заг. ред. д-ра юрид. наук, доц. В. В. Сокуренка; [О. І. Безпалова, О. В. Джафарова, В. А. Троян та ін. ; передм. В. В. Сокуренка]. Харків: ХНУВС, 2017. 432 с.

9. Територіальні органи і підрозділи ДМС виявили понад 2400 порушників міграційного законодавства. URL: https://dmsu.gov.ua/news/dms/teritorialni-organi-i-pidrozdili-dms-viyavili-ponad-2400-porushnikivmigraczijnogo-zakonodavstva.html (дата звернення: 25.11.2019).

\section{References}

1. Konstytutsiia Ukrainy: pryiniata Verkhovnoiu Radoiu Ukrainy 28 chervnia 1996 roku [Constitution of Ukraine dated June 28, 1996]. (1996). Vidomosti Verhovnoi Rady Ukrainy - Verkhovna Rada of Ukraine Review,30, 33 [in Ukrainian].

2. Pro natsionalnu politsiiu: Zakon Ukrainy vid 02.07.2015 [Law of Ukraine «On National police» dated July 02, 2015]. (2015). Vidomosti Verhovnoi Rady Ukrainy - Verkhovna Rada of Ukraine Review, 40-41, 379 [in Ukrainian].

3. Pro immihratsiiu: Zakon Ukrainy vid 07 chervnia 2001 roku. [Law of Ukraine «On immigration» dated June 07, 2001]. (2001). Vidomosti Verhovnoi Rady Ukrainy - Verkhovna Rada of Ukraine Review, 41, 197 [in Ukrainian].

4. Pro pravovyi status inozemtsiv ta osib bez hromadianstva: Zakon Ukrainy vid 4 liutoho 1994 roku [Law of Ukraine «On legal status of foreigners and stateless people» dated January 4, 1994]. (1994). Vidomosti Verhovnoi Rady Ukrainy - Verkhovna Rada of Ukraine Review, 23 [in Ukrainian].

5. Pro Derzhavnu prykordonnu sluzhbu Ukrainy: Zakon Ukrainy vid 3 kvitnia 2003 roku [Law of Ukraine «On state border service of Ukraine» dated April 3, 2003]. (2003). Vidomosti Verhovnoi Rady Ukrainy - Verkhovna Rada of Ukraine Review, 27 [in Ukrainian].

6. Pravyla vizdu inozemtsiv ta osib bez hromadianstva v Ukrainu, yikh vyizdu z Ukrainy i tranzytnoho proizdu cherez yii terytoriiu: Postanova Kabinetu Ministriv Ukrainy vid 29 hrudnia 1995 roku № 1074 iz zminamy ta dopovnenniamy stanom na 04 veresnia 2009 [Decree of Cabinet of Ministries of Ukraine «Rules for entry of foreigners and stateless persons to Ukraine, their departure from Ukraine and transit passage through its territory» dated December 29, 1995]. (1995). Zbirnyk Postanov Ukrainy - Collection of resolutions of Ukraine, 4 [in Ukrainian].

7. Pro zaprovadzhennia novoho poriadku oformlennia vizovykh dokumentiv dlia vizdu v Ukrainu: Postanova Kabinetu Ministriv Ukrainy vid 20 liutoho 1999 roku № 227 [Decree of Cabinet of Ministries of Ukraine «On introduction of a new procedure for issuing visa documents for entry into Ukraine» dated February 20, 1999]. (1993). Ukrainskyi chasopys prava i polityky - Ukrainian Law and Policy Review, 3 [in Ukrainian].

8. Administratyvna diialnist orhaniv politsii Ukrainy [Administrative activities of the police of Ukraine]: pidruchnyk / za zah. red. d-ra yuryd. nauk, dots. V. V. Sokurenka ; [O. I. Bezpalova, O. V. Dzhafarova, V. A. Troian ta in.; peredm. V. V. Sokurenka]. (2017). Kharkiv: KhNUVS [in Ukrainian].

9. Terytorialni orhany $i$ pidrozdily DMS vyiavyly ponad 2400 porushnykiv mihratsiinoho zakonodavstva [Territorial authorities and units of the LCA found more than 2400 violators of migration law]. Retrieved from: https://dmsu.gov.ua/news/dms/teritorialni-organi-i-pidrozdili-dms-viyavili-ponad-2400-porushnikivmigraczijnogo-zakonodavstva.html [in Ukrainian]. 